\title{
Diplomatic Mobility and Persuasion between Rome and the West (I-II AD) ${ }^{1}$
}

\author{
Elena Torregaray Pagola
}

\section{1 \\ Introduction}

Part of Augustus' discourse in the Res Gestae reviews the numerous legationes-embassies he received. Their mention served to mark the borders of the empire and to highlight its vastness. ${ }^{2}$ Yet, from the viewpoint of what could be considered as Rome's international relations, a new phase was actually set during which the intensity of diplomacy between Rome and the various communities it was related to (as a result of territorial expansion), as well as Rome's control over her boundaries, considerably decreased. The peak of diplomatic exchange had been reached in the Republican period in the second century BC. It noticeably declined from the first century вС onwards. Within the empire, once the conquest was completed, political communication with Rome was arranged differently. This, at any rate, is the viewpoint of modern historiography which makes a clear distinction between diplomacy, as a tool of external relations between sovereign states on the one hand, and political communication, intended at shaping internal relationships within a state on the other. ${ }^{3}$ However, from a Roman point of view, at least in terms of wording, the situation did not change much as Romans did not differentiate between diplomacy and political communication: to them it invariably consisted of the dispatch of a legatio, a mission. ${ }^{4}$ This approach, closer to modern considerations

1 This research has benefited from funds from MINECO HAR2013-42615-P.

2 RG 31-33. C. Nicolet. L'Inventaire du monde: Géographie et politique aux origines de l'Empire romain (Paris 1988).

3 The term 'political communication' referring to the internal diplomacy in the Roman empire has been extracted from A. Gillett, Envoys and Political Communication in the Late Antique West 411-533 (Cambridge 2003).

4 F. Millar, 'Government and diplomacy in the Roman Empire during the first three centuries', The International History Review 10 (1988), 345-377; G. Ziethen, Gesandte vor Kaiser und Senat. Studien zum römischen Gesandtschaftswesen zwischen 30 v. Chr. und 117 n. Chr. (St. Katharinen 1994), 1-6; J. Edmonson, 'The Roman Emperor and local communities of the Roman Empire', in J.-L. Ferrary and J. Scheid, eds., Il princeps romano: autocrate o magistrato? Fattori giuridici 
of the transnational nature of external relations whereby the internal and external policy of a state do not differ, should nonetheless be qualified. Such a differentiation did not actually apply within the Roman empire. This might lead us to question the existence of a genuine external policy in Rome and possibly to consider the term 'policy' itself quite anachronistic.

Apart from these preliminary considerations of terminology, what is undeniable is that since the war against Pyrrhus, and even more so since the Second Punic War, a new pattern of diplomatic mobility can be detected in the Mediterranean. It is linked to the rise of Rome's centrality. All those communities wishing to negotiate or ratify their submission to Rome began to send embassies to the city. It generated a constant flow that over time came to alter the capacity to receive within the city itself. The flow was constant and regular from the second century вС onwards. It amplified the previous movement taking place in the theatres of conquest, when the Roman general redirected the embassies sent to him to the central point from which the military campaign was organized-usually his camp. These lesser movements established in the area of conquest were replaced by a larger flow aimed at the city of Rome. Thus Rome organized diplomatic mobility, attracting a large number of embassies in February, the month appointed by the Senate for their reception during the Republic. In all likelihood the official date of February, established already in the lex Gabinia, had an impact on the travelling arrangements of ambassadors, who sometimes had to face a long journey, in order to reach the city in time. Under the empire, the reception procedure was altered since the main objective of the legationes was to be received by the princeps. ${ }^{5}$ Dates were therefore altered and concentrated in the summer and autumn. The location of the reception was no longer strictly limited to the city of Rome, but to wherever the princeps happened to be. However, the pattern of diplomatic mobility in imperial times continued to be aimed largely at the city of Rome.

Nevertheless, the mobility of people concerned with political communication and diplomacy did clearly decrease from the late first century вс onwards. Rome sent out hardly any envoys and limited itself to receiving legationes from cities and provinces. G. Souris observed on the basis of attestations in the epigraphic sources that the embassies cluster in the early stages of the Principate,

e fattori sociali del potere imperiale da Augusto a Commodo. Istituto Universitario di Studi Superiori (Pavia 2015), 127-129.

5 C.D. 53. 21. 6; 33.1-2. F. Hurlet, 'Les ambassadeurs dans l'Empire romain. Les légats des cités et l'idéal civique de l'ambassade sous le Haut-Empire', in A. Becker-Piriou and N. Drocourt, eds., Ambassadeurs et ambassades au cœur des relations diplomatiques. Rome-Occident médiévalByzance (VIII ${ }^{e}$ s. av.J.-C.-XII ${ }^{e}$ s. ap.J.-C.) (Metz 2012), 110-118. 
with Augustus and then Claudius receiving the most. ${ }^{6}$ Later in the imperial period, the bulk of diplomatic communication occurs in the second century $\mathrm{AD}$, in the Antonine period, while its volume drastically diminished in the first half of the third century AD.

Were we to outline a map of diplomatic mobility within the territory of the empire, a clear difference in terms of the provenance of legationes can be observed. Arrivals from western provinces were notably fewer than those from the eastern zone of the empire. ${ }^{7}$ Such a disparity, however, is no novelty compared to the Republican period, when it was even more pronounced. ${ }^{8}$ The works of F. Canali de Rossi, detailing the number of embassies sent from the Greek world to Rome in the Republic, clearly show much higher diplomatic mobility in this area than in the west. In this sense, there is continuity in terms of diplomatic practice within the Roman system between the Republic and the empire. Different diplomatic cultures, much more developed in Hellenic territories than in the west, unquestionably had an influence on this unequal distribution and the mobility of legationes. The usual practice of sending embassies, widespread in the Greek world in classical and Hellenistic times, continued throughout the Republican and imperial periods. It was a fully established means of communication and its goals simply needed to be redirected after the Roman conquest. In the west, however, this procedure was relatively new. Literary sources seem to claim it responded to necessity and was much more local and circumstantial than in Greek diplomatic practice. For instance, Massilia, a Greek city in the west, maintained abundant diplomatic relations with Rome during the Republic, attesting to a diplomatic culture linked to Greek tradition rather than to western practices. This distinctive behaviour of the east and the west in terms of diplomatic mobility persisted during the

6 G. Souris, Studies in Provincial Diplomacy under the Principate (diss. Cambridge 1984), 78.

7 C. Habicht, 'Zum Gesandtschaftsverkehr griechischer Gemeinden mit römischen Instanzen während der Kaiserzeit', Archaiognosia 11 (2001/2002), 11-28; W. Eck, 'Diplomacy as a part of the administrative process in the Roman empire', in C. Eilers, ed., Diplomats and Diplomacy in the Roman World (Leiden and Boston 2009), 193-208.

8 F. Canali de Rossi, Le ambascerie dal mondo greco a Roma in età republicana (Rome 1997); E. Torregaray Pagola, 'Embajadas y embajadores entre Hispania y Roma en la obra de Tito Livio', in idem and Y. Santos Yanguas, eds., Diplomacia y autorrepresentación en la Roma antigua (Vitoria-Gasteiz 2005), 25-62; A.M. Sanz, 'Rome et les communautés hispaniques: des ambassadeurs face à l'émergence d'un pouvoir hégémonique (fin $\mathrm{III}^{\mathrm{e}}-\mathrm{II}^{\mathrm{e}}$ siècle av. J.-C.)', in A. Becker-Piriou et N. Drocourt, eds., Ambassadeurs et ambassades au coeur des relations diplomatiques. Rome-Occident médiéval-Byzance (VIII ${ }^{e}$ s. av. J.-C.-XII ${ }^{e}$ s. ap. J.-C.) (Metz 2012), 31-63; E. García Riaza, 'Legati ad Caesarem. Instituciones diplomáticas indígenas en el “Bellum Gallicum”, Veleia 26 (2009), 47-62. 
empire, probably due to diverse traditions. Nonetheless inscriptions register a slight increase in the number of tributes to ambassadors from the second century AD onwards in the west, which may indicate that these communities too started to regard diplomatic service as a source of honour for their city notables.

Following W. Eck and F. Hurlet, it might be claimed that the initiative to send embassies to the princeps in the west was conditioned by mediation of officials in power, such as the provincial governor. ${ }^{9}$ They could exert great influence in the final decision of dispatching a legatio, which usually would be based on practical issues which were mostly economic. Nonetheless I believe that we need to take into consideration the fact that western communities were immersed in forms of diplomacy whereby relationships with the centre of the Roman empire revolved around models laid down by the different imperatores from the time of the conquest, based on what they viewed as less developed diplomatic tools than their own. In this sense Rome dealt differently with the east by implementing the existing diplomatic culture and adapting to it. As a result, during the empire, eastern communities took the initiative when sending embassies to the princeps.

Diplomatic Mobility in the West

An analysis into the dispatch of embassies from the western territories of the empire must take into consideration in the first place why these envoys were sent. As legationes were part of a process of self-representation of the community, their typology is intimately linked to the new role attributed to western provinces in Rome's imperial structure both from the viewpoint of administration and ideology. ${ }^{10}$ Thus, a communication policy developed from the first to the third century $\mathrm{AD}$ in which relationships mostly revolved around the figure of the princeps-though embassies were also sent to the Senate or the provincial governor in an attempt to relieve the emperor's workload-and representatives of local and provincial administration. Once Roman administration and management were settled after military conquest, the purpose of most of

A. Bérenger, 'Les relations du gouverneur avec les notables provinciaux: cérémonial et sociabilité, in N. Barrandon et F. Kirbihler, eds., Les gouverneurs et les provinciaux sous la République romaine, (Rennes 2011), 171-187; Idem, Le métier de gouverneur dans l'empire romain (Paris 2014), 367-401.

$10 \quad$ Hurlet 2012, op. cit. (n. 5), 101-126; J.F. Rodríguez Neila, 'Las legationes de las ciudades y su regulación en los estatutos municipales de Hispania', Gerión 28 (2010), 223-273. 
the known legationes was to acknowledge the figure of the emperor and to deal with local administrative issues. ${ }^{11}$ They fulfilled a dual objective: loyalty to the princeps was displayed, but at the same time the praise and the journey, far from being pointless, were used for the benefit of their community. This was a game of recognition of power, exhibited in the praises uttered by the legati and also a display of the princeps' generosity and euergetism. ${ }^{12}$

Bearing this in mind, it can be argued that most of the known legationes attested in literary and epigraphic sources consisted of expressions of loyalty to the princeps from the western territories. Because of this fact, it must also be pointed out that these are all successful legationes. The possible failures in political communication between the two parties, which probably did occur, are practically unknown to us. ${ }^{13}$

Furthermore, the recorded legationes, beyond their political aim, contributed to the design of a specific image of the empire supporting the historicalliterary construction of an unambiguous image of the emperor. Quite probably, though not certainly, by comparison with what happened in the east, the definition of the relationship of the city with the princeps played a prominent role in the agenda of the main municipal and provincial assemblies in the west. ${ }^{14}$ In consequence, both the petitions the city wished to put before the emperor must have been dealt with as well as the necessary acknowledgement of events concerning the imperial rule, births, deaths, successions, celebration of victories, etc. The city or the province sought to demonstrate its loyalty, but it was also necessary to establish good relations which could later procure benefits for the community.

In terms of chronology, literary and epigraphic sources recording political communication between the western territories and Rome during the empire notably accumulated in the Julio-Claudian period, slightly decreased during the Flavian dynasty and increased again during the Antonine period, the first and last being the most abundant, possibly because these were times of reinforcement of the imperial institution. There is also a clear difference between

11 F. Millar, The Emperor in the Roman World (31 BC-337 AC) (London 1977), 218; F. Kayser, 'Les ambassades alexandrines à Rome (I-II siècle)', Revue des Études Anciennes 105 (2003), 440.

12 T.R. Stevenson, 'The ideal benefactor and the father analogy in Greek and Roman thought', Classical Quarterly 42.2 (1992), 421-436.

13 T. Corey Brennan, 'Embassies gone wrong: Roman diplomacy in the Constantinian Excerpta de Legationibus', in C. Eilers, ed., Diplomats and Diplomacy in the Roman World (Leiden and Boston 2009), 171-192.

14 H. Fernoux, Le demos et la cité: Communautés et assemblées populaires en Asie Mineure à l'époque impériale (Paris 2011), 275. 
the types of sources. Literary sources are more abundant in the Julio-Claudian period, coinciding with the evident tribute historiography pays to the recently created and established imperial institution, while in the Flavian and Antonine period in the west, epigraphic testimonies are more abundant regarding legationes, which might confirm the trend towards greater interaction between the parties within the system and the increased efficiency of local and provincial institutions, who dispatched legationes to the princeps. ${ }^{15}$

An analysis of the corpus of documents reveals immediately that in the Julio-Claudian period, Augustus and Claudius were the emperors who received the highest number of legationes from the west and, in general, from the entire empire. ${ }^{16}$ The concentration of embassies sent to these emperors is, without a doubt, the result of the need to receive extraordinary legitimacy both from the founder of the Principate and his successors. All of the embassies sought to differing and varying extents to demonstrate the loyalty of the western provinces towards the emperor. They revolved around three topics.

Firstly, the gifts presented in acknowledgment of the victories of the empire, presumably contributions to the glory of Rome thanks to the princeps, directly linked to the Republican custom of sending embassies of congratulations to the Senate for Rome's military triumphs. ${ }^{17}$ It might be considered an extension of the practice of the diplomatic gift, also in the Republican period, which included the habit of depositing gifts in the temple of Capitoline Jupiter acknowledging his superiority. Amongst those offered by western embassies, the most relevant are the gifts made to Augustus by Baetica, ${ }^{18} \mathrm{Gallia}$, the municipia and the colonies of Italy ${ }^{19}$ and to Claudius by the provinces of Hispania

15 S. Panzram, Stadtbild und Elite: Tarraco, Corduba und Emerita Augusta zwischen Republik und Spätantike (Stuttgart 2002), 55-57, 167, 223.

16 Souris, op. cit. (n. 6), $78-79$.

17 C. Auliard, 'Cadeaux et merchandages diplomatiques à Rome jusqu'au début de la conquête méditerranèenne', Veleia 26 (2009), 63-74.

18 CIL 6. 31267; E. Torregaray Pagola, 'Legationes cívicas y provinciales: la comunicación política entre "Hispania” y Roma en época imperial', in E. Ortiz de Urbina, ed., Los magistrados locales de Hispania: aspectos históricos, jurídicos, lingüísticos (Vitoria-Gasteiz 2013), 317-319.

19 For Italy, see $R G$ 21: Auri coronari pondo triginta et quinque millia municipiis et colonis Italiae conferentibus ad triumphos meos quintum consul remisi, "In my fifth consulship I remitted thirty-five thousand pounds weight of coronary gold contributed by the municipia and the colonies of Italy". For the Gauls, see Quint. Inst. 6.3.79: Sed eluditur et ridiculum ridiculo ut diuus Augustus, cum ei Galli torquem aureum centum pondo dedissent..., "But a joke may be evaded by a joke: the emperor Augustus was given a golden torque weighing a hundred pounds by the Gauls ..."; Ziethen 1994, op. cit. (n. 4), 245. 
citerior and Gallia Comata, which sent gold crowns to commemorate his victory over Britannia. ${ }^{20}$ All these embassies demonstrated public loyalty to the imperial institutions by acknowledging Rome's military might.

Secondly, embassies linked to family events concerning the emperor, such as the approval by Augustus of funeral honours decreed by Pisa for Lucius and Gaius, or the sending and reception of the senatusconsultum concerning the funeral honours related with Germanicus, ${ }^{21}$ or the condolences arriving from Gaul on the death of Nero's mother, Agrippina. ${ }^{22}$ The ultimate purpose of such embassies was to establish a form of partaking in the common grief, thus consolidating the imperial structure.

Thirdly, legationes concerning the institution of the imperial cult which, like the second category, renewed the links of adhesion to the princeps from a religious viewpoint. ${ }^{23}$ Generally, this type of embassy focused on petitions to build temples in honour of the emperor. ${ }^{24}$ In the case of Hispania, both Baetica and Hispania citerior dispatched petitions in the Julio-Claudian period to build temples dedicated to the cult of the emperors, demonstrating an early adoption of such practices. ${ }^{25}$

The aforementioned instances of construction of temples, condolences and congratulations for a triumph presented a specific model of loyalty to the figure

20 Plin. NH. 33.16.54: Claudius successor eius, cum de Brittannia triumpharet, inter coronas aureas VII pondo habere quam contulisset Hispania citerior, VIIII quam Gallia comata, titulis indicauit, "His successor Claudius when celebrating a triumph after the conquest of Britain, advertised by placards that among the gold coronets there was one having a weight of 7000 pounds contributed by Hither Spain and one of gooo from Gallia Comata"; Rodríguez Neila 2010, op. cit. (n. 10), 229.

21 CIL 11. 1420.33-37: '... legati ex nostro ordine ...'; 1421.42; Tab. Siar. 2b. 24-26. Rodríguez Neila 2010, op. cit. (n. 10), 226.

22 Quint. Inst. 8.5.15: Et insigniter Africanus apud Neronem de morte matris: "rogant te, Caesar, Galliae tuae ut felicitatem tuam fortiter feras", "Another distinguished example is Africanus' remark to Nero about his mother's death, 'Caesar, your provinces of Gaul beg that you will bear your happiness like a man'”; Ziethen 1994, op. cit. (n. 4), 245; Rodríguez Neila 2010, op. cit. (n. 10), 228-229.

23 D. Fishwick, The Imperial Cult in the Latin West. Studies in the Ruler Cult of the Western Provinces of the Roman Empire. Vol. 3 (Provincial Cult) (Leiden 2002).

24 B. Pouelle, 'Religion et récit historique: les ambassades des sanctuaires grecques sous Tibère (Tacite, Annales III.6o-63)', Dialogues d'Histoire Ancienne, suppl. 4.2 (2010), 343-350.

25 Tac. Ann. 4.37-38; Suet. Tib. 31; Tac. Ann. 1.88.1; Quint. Inst. 6.33.77; W.E. Mierse, Temples and Towns in Roman Iberia. The Social and Architectural Dynamics of Sanctuary Designs, from the Third Century BC to the Third Century AD (Berkeley CA etc. 1999), 54-128. 
of the princeps, confirming the image provided by the literary sources of adhesion and fidelity of the provincial and local communities involved.

After the Flavian reorganization, the perfecting of Rome's administrative system accelerated and advanced. Sources-which become mostly epigraphic-regarding the practice of sending legationes and political communication give more information about administrative interaction between the parties, recording more than simply the devotion displayed by provinces and cities towards the princeps. Due to this, from the Flavian period onwards information is available regarding legationes dealing with specific issues in the development and administration of cities. ${ }^{26}$ Interaction between the participants as well as a greater concern about management become more prominent. The texts thus no longer deal simply with the adulation of the emperor as a conqueror or pacifier but also emphasize his role as organizer and manager of the empire. An example of this change in the terms of political communication can be found in the letters sent by Vespasian and Titus to Sabora ${ }^{27}$ and Munigua, ${ }^{28}$ respectively. They reflect the intervention of the princeps in matters concerning the management of the cities, which are the result of the respective legationes dispatched with the purpose of receiving the favours of both emperors. ${ }^{29}$

The continuous renovation of the imperial institution was further boosted by the coming to power of the Antonines. In this period, the number of received legationes increased, no doubt in order to renew commitment to the empire. Preserved documentation continues to be mostly epigraphic and reveals a flow of political communication in continuity with former practices. Antoninus Pius and Hadrian are now the emperors receiving the most embassies. ${ }^{30} \mathrm{We}$ also know that Hadrian was one of the few emperors who, like Augustus, personally travelled to the Iberian peninsula around the years $122-23 \cdot{ }^{31} \mathrm{He}$ spent the winter in Tarraco, as did his predecessor, and, according to the Historia Augusta, it was to this place that he called the inhabitants of Spain, probably

26 P. Le Roux, La Péninsule Ibérique aux époques romaine (206 avant J.-C-4og ap.J.-C.) (Paris 2010), 126-127.

27 CIL 2/5. 871 = ILS 6o92; J. González, Bronces jurídicos romanos de Andalucía (Sevilla 1990); A. D’Ors, Epigrafía jurídica de la España romana (Madrid 1953) 61-63, n. 4.

28 HAE (Hispania Antiqua Epigraphica), 12-16, 1923 = AE 1962, 288. González 1990, op. cit. (n. 27), 169-170, n. 13; Rodríguez Neila 2010, op. cit. (n. 10), 230.

29 Eck 2009, op. cit. (n. 7), 193-195.

$30 \quad$ Souris 1984 , op. cit. (n. 6), 78-79.

$31 \quad C I L 2.4201=R I T 331=I L S$ 6927; Le Roux 2010, op. cit. (n. 26), 132-133. 
driving the movement of many legationes from different places of Hispania to the capital of the province Citerior. ${ }^{32}$

From the Antonine period onwards, advances were made in forms of political communication. In preserved documentation, mostly epigraphic, greater prominence is given to the legati rather than to the princeps. Tributes paid to them for their 'diplomatic' endeavour now provide most information about legationes. They confirm the increasing significance attached to the notables in the cities and to representatives of the provincial assembly presenting their initiatives to the emperor. But one of the most meaningful aspects of these homages from the point of view of diplomatic practice in the empire is the fact that the usefulness of embassies is measured in terms of the success of their dealings. In some inscriptions recording embassies coming from Hispania and Africa the idea that prosperitas is an essential element attached to the legatio is highlighted, ${ }^{33}$ as well as the utilitas for and the satisfaction of the community, from the successful dealings carried out by the embassy. While conclusions are obviously qualified by the hazards of preservation of available documents, it seems clear that the level of success of the mission constituted an indispensable element in the public perception of the usefulness of legationes dispatched from the western territories to Rome or to an audience with the emperor.

At this point, we might ponder the aforementioned difference in the amount of embassies sent by the western territories compared to those sent from the east. A passage in Suetonius' biography of Tiberius describes the difficulties that some ambassadors from Africa-legati ex Africa-experienced in being received by the princeps, causing an unnecessary and unwanted delay in their dealings. Although the passage is ironic about Tiberius, Tacitus as well shows the emperor leaving diplomatic affairs - from the east—in the hands of the

HA, Hadr. 12, 3-4: Omnibus Hispanis Tarraconem in conuentum uocatis dilectumque ioculariter, "To this place, too, he called all the inhabitants of Spain for a general meeting, and when they refused to submit to a levy..."; Aul.Gel. NA 16. 13. 4: De cuius opinionis tam promiscae erroribus diuus Hadrianus in oratione, quam de Italicensibus, unde ipse ortus fuit, in senatu habuit, peritissime disseruit mirarique se ostendit, quod et ipsi Italicenses et quaedam item alia municipia antiqua, in quibus Vticenses nominat, cum suis moribus legibusque uti possent, in ius coloniarum mutari gestiuerint, "With regard to the errors in this opinion which is so general the deified Hadrian, in the speech which he delivered in the senate On Behalf of the Italicenses, from whom he himself came, discoursed most learnedly, showing his surprise that the Italicenses themselves and also some other ancient municipia, among whom he names the citizens of Utica, when they might enjoy their own customs and laws, desired instead to have the rights of colonies". 
consuls, thwarting the initial objective of the embassy of dealing with him. ${ }^{34}$ In this case, there is no difference between east and west, but it is possible that the difficulty of reaching the emperor added a complication to sending legationes from the west, whose diplomatic practice was weaker. Taking into consideration the expense for legati to stay in Rome or wherever the princeps might have been at the time, it is plausible that pressure for success and straightforward access to the emperor where crucial issues when deciding to dispatch embassies by the western local and provincial assemblies. ${ }^{35}$ Lobbies are widely known to have existed in Rome from the Republic onwards. They strove to help diplomatic missions seeking support from the most prominent politicians in the city. However, their presence might also have hindered the work of ambassadors whose endeavours perhaps did not meet a satisfactory conclusion, at least within a relatively short period of time. In this respect, G. Souris's thesis regarding western legationes stipulating that it was generally embassies from large and prestigious cities that were easily granted access to the emperor and that only those communities who held some significance for the emperor were received by him, could at least partially explain the scant movement of western embassies within the imperial period. Many of these embassies were redirected to other officials, a practice which could compromise their effectiveness. ${ }^{36}$ Against a background where probably the laudatio to the princeps included in any legatio had to be replied to by a munificent action from the emperor or with a sign of favour or benevolence towards the applicants, it was extremely important to secure a direct interview with the emperor. Failure to do so could almost be considered a failure of the legatio. It would be reasonable to believe that the emperor himself, on some occasions, would avoid receiving ambassadors so as to deter further missions. This is the reason why the preserved tributes, some of which contain an acknowledgement of success, may not have referred solely to the outcome of negotiations but to the fact of having managed to reach the princeps himself. ${ }^{37}$

The suggestion of W. Eck that western communities eventually found it much more efficient to resort to the provincial governor rather than taking on the costly effort of dispatching a legatio to the emperor is therefore plausible. Such a practice might be connected with the formula used in a series of diplomatic inscriptions dated in the second and third centuries AD and found in the African city of Volubilis containing testimony to the negotiations

\footnotetext{
34 Suet. Tib. 31. 2; Tac. Ann. 3.6o-63.

35 Souris 1984, op. cit. (n. 6), 163-171.

36 Ibidem.

37 Kayser 2003, op. cit. (n. 11), 456-460.
} 
between the gens of the Baquates and the procurator of the province who, on behalf of the emperor, signed or ratified the peace with a people on the fringes of the empire. ${ }^{38}$ The fact that these inscriptions refer to a series of colloquia, meetings to build a relationship between both peoples, though not strictly in bilateral terms, might support the idea that the provincial governor took on a good deal of the diplomatic work which in principle corresponded to that of the emperor.

The economic impact on different western communities which the dispatch of legationes must have entailed cannot be overlooked. As many of these embassies, especially from the Flavian period onwards, dealt precisely with economic difficulties for those communities this must have also acted as a deterrent. The mention on inscriptions from Africa, Sicily (Malta) and Hispania of individuals who either cover the expenses of a specific legatio or offer to do so in perpetuity to favour the civic community must be highlighted in this context. ${ }^{39}$

\section{Persuasion and Western Embassies}

Beyond mere considerations of quantity, an indication that possibly supports the notion that some differences existed between the type of diplomatic mobility in the east and the west could be how sources deal with the most significant component of any embassy: powers of persuasion. While no differences exist in the motives why legati from cities and provinces would travel to see the princeps, the fact remains that up until the third century AD descriptions of the abilities and rhetorical skills of western embassies are scarce. Whereas Tacitus expounds in detail upon the rhetorical arguments of some of the legates of Greek cities arriving in Rome, little is known about the arguments and techniques of persuasion used by western ambassadors. Information is mostly practical, recording what was requested and the outcome of the negotiation. The deployment of brilliant rhetoric does not seem to have been a priority for them. By contrast, embassies from the east seem to have put more effort in preparing for their encounters with the princeps. This, once more, supports the

$38 \quad$ IAM 2.2.349; 350; 353; 356; 357; 358; 359; 360; 384; 402. J. Kolendo, 'Les inscriptions de Volubilis et les relations diplomatiques entre les romains et la tribu des Baquates', Archaelogia 57 (2006), 45-50. 
notion that within their institutions this was a common practice from which they drew greater benefits. Therefore more importance was attached to it. ${ }^{40}$

As pointed out above, the need for these legationes to succeed was directly linked to their persuasive abilities ${ }^{41}$ which in turn directly depended on the benevolence of the princeps. Quite often, given their honorary nature, embassies were clearly laudatory. A large number of them, in order to take advantage of the long journey and the cost of the embassy, combined the need to please the princeps and to procure advantages for their communities' position within the empire. Frequently enough, these embassies would exchange honours for favours as they needed to attract the emperor's benevolence before putting forward their requests. ${ }^{42}$ This guideline was followed, for instance, by the offering of honorary patronages or duumvirates to the emperor or to members of the imperial family. 43

In this context of praise and commendation it is quite striking that Plutarch, in his political advice, claims that ambassadors needed to show courage when speaking before the emperor:

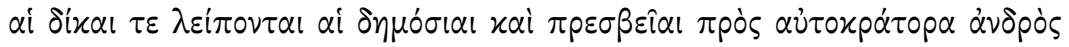

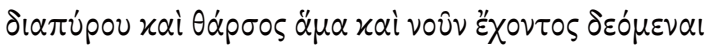

There remain the public lawsuits and embassies to the emperor, which demand a man of ardent temperament and one who possesses both courage and intellect. ${ }^{44}$

In the earlier Republican period, when the need to submit to Roman power by many embassies arriving in Rome was essential, setting forth conditions for an alliance with the Romans or reiterating alliances were the recurrent topics amongst foreign legationes. The attitude of ambassadors requesting favours from Rome was defined by a line drawn between the supplication demanded from enemies and the acknowledgement of Rome's power expected from friends. Similarly, the tasks of Roman embassies sent to those communities clearly fluctuated between posing demands on friends and intimidating enemies, which both required resolve and, above all, courage, on the side of the Roman ambassadors.

\footnotetext{
40 J. Edmonson 2015, op. cit. (n. 4), 701-729.

41 Men. Rh. 423; Rodríguez Neila 2010, op. cit. (n. 10), 264.

42 Kayser 2003, op. cit. (n. 11), 443-444.

43 Rodríguez Neila 2010, op. cit. (n. 10), 229.

44 Plut. Praec.ger. Rei publ. 805A.
} 
Diplomatic rhetoric during the empire was dominated by subordination to the princeps. It was essential to show loyalty to the institution and thus receive the necessary assistance for the development and well-being of the community within Rome's administrative system. In this sense, bringing an embassy to a successful conclusion was, as already mentioned, an essential element of the entire process. Yet, if we consider Tacitus' report on Tiberius' satisfaction upon listening to the "pleasant allusions" —laeta Tiberio-made in his presence by an embassy of Segestans, we must conclude that some of the success of legationes lay in the orators' capacity to persuade and convince the princeps:

et Segestani aedem Veneris montem apud Erycum, uetustate dilapsam, restaurari postulauere, nota memorantes de origine eius et laeta Tiberio.

The Segestans also demanded the restoration of the age-worn temple of Venus on Mount Eryx and told the familiar tale of its foundation; much to the pleasure of Tiberius, who as a relative willingly undertook the task. ${ }^{45}$

Although Tacitus' reference is brief it demonstrates two key points of political discourse: firstly a reference to the origins of the city, and secondly direct allusions to the emperor, which in this case referred to the relations between the gens Iulia and Venus and also with the temple of Eryx. ${ }^{46}$

Embassies may have alluded to the age-old relationship between their city or province and Rome, delving into aspects which would best enhance the loyalty_fides - of the community; in fact, this was an essential element in the discourse of embassies coming from Gallia. All the diplomatic rhetoric of a city such as Massilia, located in the west, though of Greek culture, was precisely based on its relationship of fides towards Rome. ${ }^{47}$ Likewise, allusions to the origins of the city and its relationship with Roman emperors recurred time and again. A concern for origins and a predilection for continuous exaltation appear in the titles of the main cities in Hispania, recalling the circumstances of creation and promotion of the city. ${ }^{48}$ These phenomena could also be linked to 'kinship diplomacy' or diplomacy established on the basis of a common origin of the communities involved. This element may have been used by embassies

\footnotetext{
45 Tac. Ann. $4 \cdot 43$.

46 B. Poulle, 'Religion et récit historique: les ambassades des sanctuaries grecs sous Tibère (Tacite, Annales III, 60-63', Dialogues d'histoire ancienne 4 (2010), 343-35.

47 D. Roman, 'Marseille et la fides de Rome', Revue archéologique de Narbonnaise 23.1 (1990), 213-220.

48 Le Roux 2010, op. cit. (n. 26), 230.
} 
coming from Saguntum, a western city of Greek origin, though this diplomatic practice was uncommon in others diplomatic cultures in the West. ${ }^{49}$

When elements to attest to a relationship of loyalty or proximity were lacking, the appearance of a wonderful feature that could attract the princeps' attention towards a city so far unknown to him could be resorted to. For example, Pliny the Elder reports the embassy from the city of Olisipo in Lusitania to inform the emperor Tiberius of the presence of a Triton on their shore, located precisely on the border of the empire:

Tiberio principi nuntiauit Olisiponiensium legatio ob id missa, uisum auditumque in quodam specu concha canentem Tritonem qua noscitur forma. et Nereidum falsa non est, squamis modo hispido corpore etiam qua humanam effigiem habet. namque haec in eodem spectata litore est, cuius morientis etiam cantum tristem accolae audiuere longe, et Diuo Augusto legatus Galliae conplures in litore apparere exanimes Nereidas scripsit.

An embassy from Lisbon sent for the purpose reported to the Emperor Tiberius that a Triton had been seen and heard playing on a shell in a certain cave, and that he had the well-known shape. The description of the Nereids also is not incorrect (...); for a Nereid has been seen on the same coast (...); also the governor of Gaul wrote to the late lamented Augustus that a large number of dead Nereids were to be seen on the shore. ${ }^{50}$

They were thus trying to boost the relevance of a city which was so far of little or no relevance amongst the territories of the empire.

It is also probable that many of these cities, besides referring to history or mythology also used more realistic persuasive techniques such as referring to population increase or to their capacity to act as solid defensive strongholds. ${ }^{51}$

Nevertheless, it is quite interesting that western embassies do not appear to have excelled in rhetorical matters, ${ }^{52}$ in contrast to Greek ones, whose forms

\footnotetext{
49 Sil. 1.265-294; Torregaray Pagola 2013, op. cit. (n. 18), 330-331; M.T. Schettino, 'Sagunto e lo scoppio della guerra in Silio Italico', Aevum Antiquum 6 (2006), 53-63.

50 Plin. NH. 9. 5 (4).9.

$5^{1}$ I. Savalli-Lestrade, 'Devenir une cité: Poleis nouvelles et aspirations civiques à la basse époque hellenistique', Citoyenneté et participation à la basse époque hellénistique (Genève 2005), 12.

Poulle 2010, op. cit. (n. 46), 343-350.
} 
of addressing the emperor are even mentioned alongside the oratory skills of the legati and the originality of their arguments. There are no traces in the west either of what A. Chaniotis refers to as 'affective diplomacy' which significantly enriched the rhetoric of Greek embassies in the Republican period. ${ }^{53}$ Quintilian only quotes the incident of the palm on the altar of Augustus in Tarraco; and mentions the condolences to Nero on the death of his mother from an embassy from Gaul. ${ }^{54}$ In general, the only evidence left from western legationes consists of the successful dealings of the ambassadors and the details of their petition; no reference is made to their particular rhetorical skills. Probably one of the reasons was the fact that on the one hand they tended to use widespread and habitual formulas of praise while on the other hand they used formulaic language matching the petitions they made. This obviously limited rhetorical originality; moreover, Latin writers may not have been inclined to record diplomatic expressions that were considered commonplace.

In this respect, I believe that in order to understand such a context in which the diplomatic act is more significant than the rhetoric used, it is useful to go back to the inscriptions found in Volubilis recording the negotiations between the gens of the Baquates and the governor of the province of Mauritania Tingitana, acting on behalf of the emperor. The texts refer to a series of diplomatic colloquia aimed at signing or ratifying peace agreements. ${ }^{55}$ The repeated reference to the diplomatic act as a colloquium, negotiation, precisely stresses the existence of encounters in which a conversation was staged, that probably comprised of a series of formulas of symbolic rather than rhetorical content. ${ }^{56}$ Nonetheless, the epigraphic mention of the negotiations for peace as a diplomatic act is quite original in this western area of the Roman empire, all the more so if we bear in mind that it entailed the regular mobility of the Baquates to reiterate the ties of alliance linking them to the Romans.

53 A. Chaniotis, 'Affective Diplomacy: Emotional scripts between Greek communities and Roman authorities during the Republic', in D. Cairns and L. Fulkerson, eds., Emotions between Greece and Rome (London 2015), 87-103.

54 Quint. Inst. 6.3.77: Et Augustus, nuntiantibus Terraconensibus palmam in ara eius enatam, "apparet" inquit "quam saepe accendatis", "Again, Augustus remarked, when the citizens of Tarraco reported that a palm tree had grown on his altar, 'Now we know how often you light the fire on it'”; 8.5.15. Ziethen 1994, op. cit. (n. 4), 244-245.

55 N. Brahmi, 'Les colloquia romano-baquates: patronage divine et intégration', in R. Compatangelo-Soussignan and C.G. Schwentzel, eds., Étrangers dans la cité romaine (Rennes 2007), 155-170.

$5^{6} \quad$ e.g. IAM 2.2.350 (conlocutus). 


\section{Conclusions}

It can be concluded that the emperors' need for legitimation and adhesion to themselves, their families and the imperial institution created a reduced though constant flow of ambassadors between western communities and Rome, for mutual benefit. Legationes contributed to the increase of the visibility of these communities before the princeps; that is, those who could afford this type of mobility. And the emperor saw his position of power constantly reinforced as a result of the constant wish of local and provincial embassies to have direct access to him. What is more, the establishment of Rome's administrative system contributed to exposing a series of management issues which prompted the mobilization of local and provincial elites seeking the favour of the princeps in solving the financial problems of their communities.

As a result, a pattern was created of diplomatic mobility from the western periphery towards the centre of power. Scarce as testimonies to this mobility may be, they reveal a continued relationship between western provinces and the highest representative of power in Rome.

San Sebastián, January 2016 